\title{
ANALYSIS OF LAND USE AND OCCUPANCY IN PERMANENT PRESERVATION AREAS ACCORDING TO THE HYDROGRAPHY OF RIBEIRÃO ÁGUA FRIA - BOFETE, SP - BRAZIL
}

\author{
RAFAEL C. NARDINI ${ }^{1}$, SÉRGIO CAMPOS ${ }^{2}$, LUCIANO N. GOMES ${ }^{3}$, \\ KATIUSCIA F. MOREIRA ${ }^{4}$, MARIANA W. DE T. PIZA ${ }^{5}$
}

\begin{abstract}
The use conflicts are determined by the inadequate occupations of the soil, as it is the case of soil occupation inside of permanent preservation areas. This study aimed to determine the classes of the soil use and if there are conflicts inside of permanent preservation areas along the drainage network of the Água Fria Stream watershed, located in Bofete city - São Paulo, Brazil. It locates geographically between the coordinates: $48^{\circ} 09^{\prime} 30^{\prime \prime}$ to $48^{\circ} 18^{\prime} 30^{\prime \prime}$ longitude WGr., $22^{\circ} 58^{\prime} 30^{\prime \prime}$ to $23^{\circ} 04^{\prime} 30^{\prime \prime}$ latitude $\mathrm{S}$, with an area of 15242.84 ha. The map of soil use was elaborated through the interpretation directly in the computer screen of satellite digital image. In the orbital data, the study area is inserted in the quadrant A, of image TM/Landsat - 5, orbit 220, point 76, passage $9 / 8^{\text {th }} / 2007$. The Geographical Information System used was CartaLinx. The conflict areas of the watershed were obtained from the crossing between the maps of soil use and of PPAs. The results allowed the conclusion that more than half of the area (51.09\%) is occupied by pastures, reflex of sandy soils and low fertility. It was also verified that although almost half of the watershed is covered with some type of vegetation ( $48.78 \%$ of natural forest /reforestation), it has approximately a third of permanent preservation areas used inappropriately by pastures $(88.15 \%)$, reforestation $(10.42 \%)$ and exposed soil (1.43\%), totaling 343.07ha of conflicting areas, in a total of 993.26 ha of PPAs.
\end{abstract}

KEYWORDS: watershed, geographic information systems, soil use.

\section{ANÁLISE DO USO E OCUPAÇÃO DO SOLO EM ÁREAS DE PRESERVAÇÃO PERMANENTE, SEGUNDO A HIDROGRAFIA DO RIBEIRÃO ÁGUA FRIA - BOFETE - SP}

RESUMO: Os conflitos de uso são determinados pelas ocupações inadequadas do solo, como é o caso de ocupação do solo dentro de áreas de preservação permanente. O presente trabalho teve como objetivos determinar as classes de uso do solo e se há conflitos dentro de áreas de preservação permanente ao longo da rede de drenagem da microbacia do Ribeirão Água Fria, município de Bofete (SP). Situa-se geograficamente entre as coordenadas: $48^{\circ} 09^{\prime} 30^{\prime \prime}$ a $48^{\circ} 18^{\prime} 30^{\prime \prime}$ de longitude

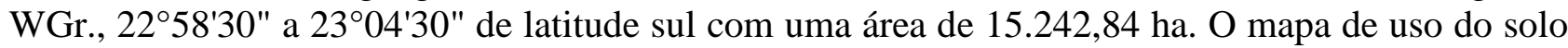
foi elaborado por meio da interpretação diretamente na tela do computador de imagem digital de satélite. Nos dados orbitais, a área de estudo está inserida no quadrante A, da imagem TM/Landsat5, órbita 220, ponto 76, passagem de 8/09/2007. O Sistema de Informação Geográfica empregado foi o Cartalinx. As áreas de conflito da microbacia foram obtidas a partir do cruzamento entre os mapas de uso do solo e de APPs. Os resultados permitiram concluir que mais da metade da área $(51,09 \%)$ está ocupada por pastagens, reflexo de solos arenosos e de baixa fertilidade. Constatou-se, ainda, que apesar de quase metade da microbacia estar coberta com algum tipo de vegetação $(48,78 \%$ de mata natural/reflorestamento), possui aproximadamente um terço das áreas de preservação permanente utilizadas inadequadamente por pastagens $(88,15 \%)$, reflorestamento $(10,42 \%)$ e solo exposto $(1,43 \%)$, totalizando 343,07 ha de áreas conflitantes em um total de 993,26 ha de APPs.

PALAVRAS-CHAVE: microbacia, sistemas de informação geográfica, uso do solo.

\footnotetext{
${ }^{1}$ Doutorando, Programa de Pós-Graduação em Agronomia - Irrigação e Drenagem, Faculdade de Ciências Agronômicas, UNESP, Botucatu - SP, rcnardini@fca.unesp.br.

${ }^{2}$ Prof. Titular, Depto. Engenharia Rural, Faculdade de Ciências Agronômicas, UNESP, Botucatu - SP,seca@ fca.unesp.br.

${ }^{3}$ Prof. Dr., Universidade Estadual de Londrina, UEL, Londrina - PR, lunago@uel.br.

${ }^{4}$ Discente do Curso de Graduação em Engenharia Florestal, FCA/UNESP, Botucatu - SP, kfmoreira@ fca.unesp.br.

${ }^{5}$ Mestranda do Programa de Pós-Graduação em Agronomia - Energia na Agricultura, FCA/UNESP, marywagner.adm@gmail.com.

Recebido pelo Conselho Editorial em: 10-6-2011

Aprovado pelo Conselho Editorial em: 5-6-2012
} 


\section{INTRODUCTION}

The planning of land use in watersheds is critical for the full development of a society do not harm them. Therefore, it is necessary a correct use of natural resources as well as effective utilization of use areas. A good utilization of used areas implies the non destruction of permanent preservation areas (PPAs) within these watersheds, because the inappropriate land use generates significant losses to the environment and increase in conflictive areas.

A clear example of the lack of planning of a watershed is the Tietê River, in São Paulo. Because it is a plain river, with increasing flow rate due to the rains, intensified in the summer, there is naturally the flow of water excess to the river banks, which causes encroachment of buildings, causing huge inconvenience to the population. This process is the result of poor planning of land use along the river banks, which has virtually no infiltration due to soil covered with concrete and asphalt.

Moreover, the use of geographic information systems (GIS) have been increasingly used in the planning of land use, because they are tools that can store large volume of data and various types of information (spatial and non-spatial ). Besides, they manipulate stored data and may generate thematic maps or numerical information more quickly and effectively. The maps generated from crossing of information are important to help in the study and planning of these areas.

Thus, in order to contribute to an environmental management plan on the Água Fria Stream watershed - in Bofete, state of São Paulo, this study aimed to draw the map of land use, as well as spatialize and delimit permanent preservation areas and conflict areas in PPAs through satellite imagery and Geographic Information System. From these results, we also tried to substantiate them according to the Brazilian Forest Code and the CONAMA Resolution, obtaining data that assist in the maintenance and preservation of PPAs areas around the watershed and which conduct further deeper studies of the development of such land use areas.

\section{MATERIAL AND METHODS}

\section{Area characterization}

The study was developed in the Água Fria Stream watershed, located in Bofete, SP - Brazil, between the geographical coordinates: $48^{\circ} 09^{\prime} 30^{\prime \prime}$ and $48^{\circ} 18^{\prime} 30^{\prime \prime} \mathrm{W}$ Gr. longitude, $22^{\circ} 58^{\prime} 30^{\prime \prime}$ and $23^{\circ} 04^{\prime} 30^{\prime \prime}$ South latitude, representing a land area of 15,242.84 ha. In mapmaking, the watershed lies at the intersection of four planialtimetric maps, from Botucatu (SF-22-R-IV-3), Conchas (SF22-X-2), Anhembi (SF-22-R-IV-LSF-22-R-IV-3 linho (SF-22-X-II-1), scale 1:50,000 (Figure 1).

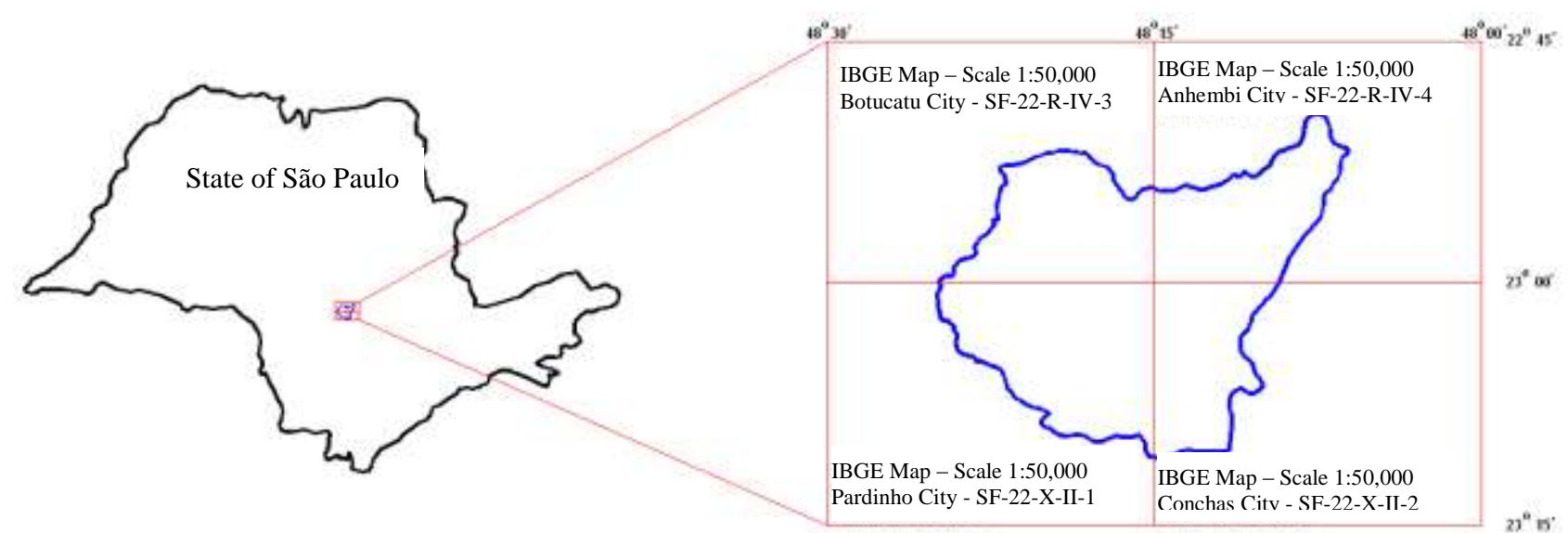

FIGURE 1. Location of Água Fria Stream watershed - Bofete, SP - Brazil.

Because it is an important and representative area of the Bofete city (SP), over the years this watershed has undergone transformations in the landscape as a result of human action. 


\section{Methodology}

For mapping the land use and occupation, it was used color composition of images from the Landsat 5 Thematic Mapper, bands 3, 4 and 5, orbit 220, point 76, quadrant A, the passage of $9 / 8^{\text {th }} / 2007$.

The georeferencing, the false color composition $(5 \mathrm{R}, 4 \mathrm{G}, 3 \mathrm{~B})$ of bands and the cut of the satellite image were performed in module Reformat/Resample of GIS - IDRISI Andes 15.0. The georeferencing of images consisted in giving a geographical meaning for each pixel of the image. The approach adopted was the image-map type, to obtain the control points with geographic coordinates. For each control point, the coordinates were determined. In georeferencing, it was used the following commands: Image - Correlate - Rubbersheet ( 88 control points). With this file, it was made a file of correspondence with the command Edit of Database Query Menu, of the Analysis module.

The vectorization of polygons and classification on screen of vector data into raster image to generate the map of land use of the watershed was accomplished through the Cartalinx software. For map creation of permanent preservation areas, as well as the crossing of this map with the land use map and generate a map of conflict of use in PPAs, it was used the ArcGis software.

The acquisition of the boundary and drainage network of the Água Fria Stream watershed was accomplished with the aid of AutoCAD Raster Design 2009 software, and the first images inserted through commands Image - Insert and Open, Next, Apply, Next and Finish, and the clipping of the watershed was conducted from the command Image - Crop - Polygonal Region.

To define the boundary of the watershed area, we followed the water dividing lines dividing (contours) of higher quotas, because they are of the highest points around the drainage; to define the drainage network, we followed up the rivers and existing water bodies in the watershed.

The outline of the study area was carried out via the Reformat menu - Window, this module was inserted into the image through the Image Files command and after that the minimum and maximum values of the vertices (geographic coordinates). Using the Display Launcher Menu of IDRISI toolbar, it was selected the option Raster Layer and, then, the composition 5, 4 and 3 was selected, which was exported from the IDRISI through the command File Export - Desktop Publishing Formats - BMPIDRIS.

The image in BMP format was imported by CartaLinx software, by Menu File-Image Conversion, through Convert Image To window. On the Menu File-New Coverage-Coverage Based Upon Bitmap, we selected the composition 5; 4 and 3, which provided higher resolution image for further vectorization of polygons in the watershed area.

The digitization of polygons was performed using the tool Begin Arc and Finish Arc of CartaLinx software. This process of polygonization originated a set of vectorized polygons on the image of the studied area. After, the classification on screen was made, taking into account elements used in photo interpretation, such as color, tone, shape, texture, grouping, size, shading, among others. Having as bottom surface the color composite of Landsat/TM images, we made the demarcation of areas (polygons) of different land uses based on the spectral behavior manifested in false color composite color for each numerical attributes. This procedure originated a map of land use.

The land use map was exported to ArcView 3.2 software, using the command File-Export, transforming the image for the ArcView Shape File (SHP) format, and the calculation of the watershed area was determined by the tool Build Polygons and Feature Properties.

According to CONAMA Resolution No. 303/2002, Article 3: "constitutes Permanent Preservation Area, the area located in marginal strip, measured from the highest level, in horizontal projection, with minimum width of thirty meters, to the watercourse of less than 10 meters wide", and the Forest Code (Law 4.771/1965), which considers these areas, covered or not by native 
vegetation: "with the environmental function of preserving water resources, landscape, geological stability, biodiversity, gene flow of fauna and flora, protect the soil and ensure the well-being of human populations". To delimit the permanent preservation areas, they were defined along the waterways of the Água Fria Stream. After importing the drainage network of watershed in SHP format (ArcView 3.2), to create a buffer of $50 \mathrm{~m}$ radius in springs and a $30 \mathrm{~m}$ buffer on either side of the drainage along the bed of the stream, thus resulting in the map of PPAs.

To identify the areas of conflict in PPAs, the procedure was performed through map algebra, where the land use map was superimposed on the map with the boundaries of the permanent preservation areas. This procedure was performed via the menu View-GeoProcessing Wizard, of the ArcView 3.2 software (Figure 2).

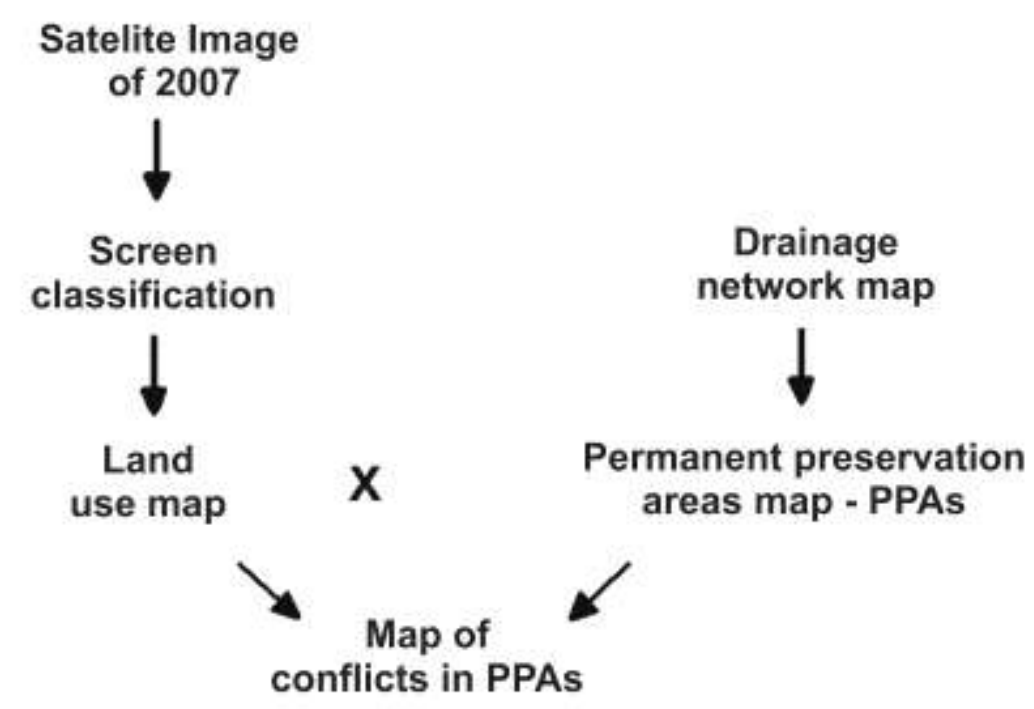

FIGURE 2. Methodological flowchart of acquisition of the map of conflict areas in PPAs.

Through the Menu C-Theme Tools-Spatial Analysis Tools, Calculate on Feature, it was possible to quantify areas of each conflict and each occupation existing in the watershed, obtained by the respective codes of each class of use.

\section{RESULTS AND DISCUSSION}

The vegetation of the watershed suffered and is suffering constant changes over the years with the action of human being, and this dynamic is more intense in places with more favorable ecological conditions, especially in relation to areas subject to agricultural exploitation.

In Figure 3, it can be observed the thematic map with the spatial distribution obtained from the visual interpretation of the five classes of land use (forest, reforestation, pasture, exposed soil and floodplain) obtained from the visual interpretation on the screen of the images of the TM/Landsat through GIS - IDRISI. The areas related to water bodies had a dark, black tone. The areas related to exposed soils had red/orange color. The areas relating to forests had a dark green tone, and the reforestation was demarcated by lighter green color and represented in the form of plots mostly. Pastures were demarcated on areas of lighter color (shades of red and pink), because according to the date of passage of the satellite image (September), they were still dry at the end of the winter season in the region, both by temperature drop and the decrease in rainfall. 


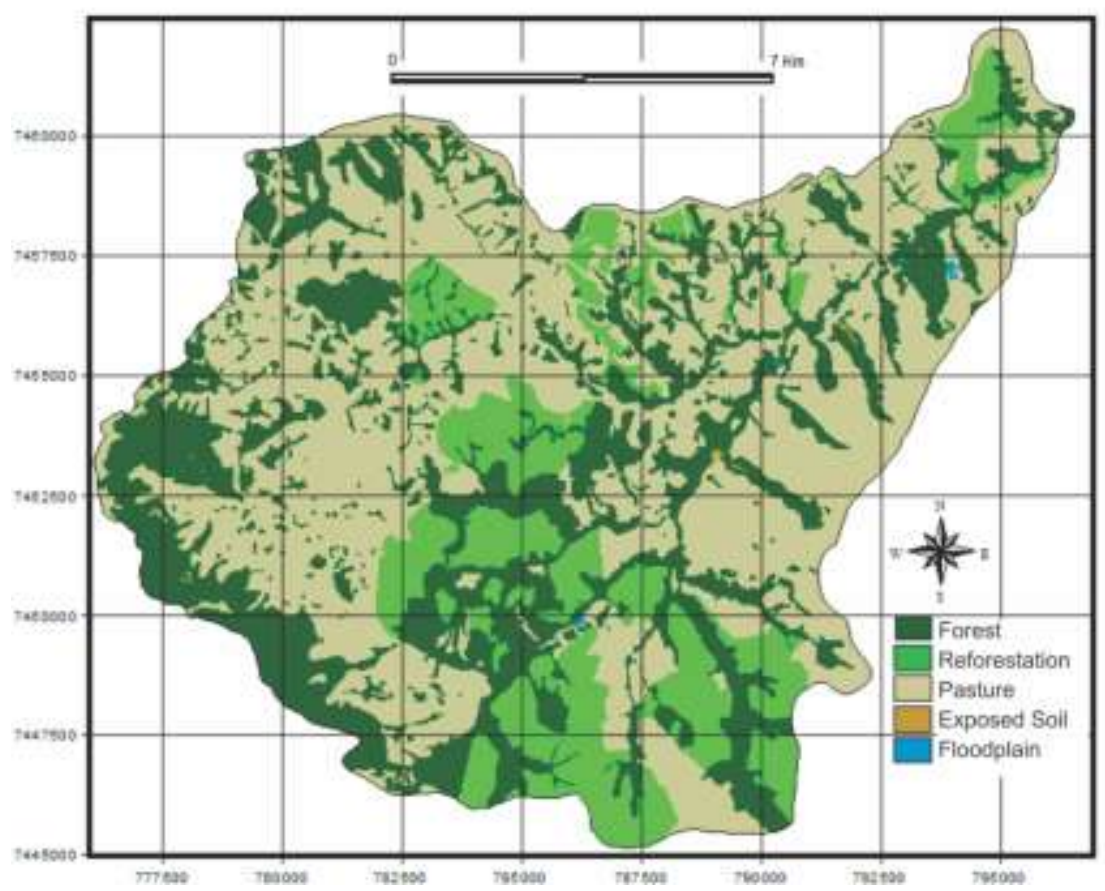

FIGURE 3. Uses and occupations in the Água Fria Stream watershed - Bofete, SP - Brazil.

According to the data obtained (Table 1), we note that there is in the watershed 4,932.9ha of natural forests $(32.36 \%)$; $2,502.9$ ha of reforestation $(16.42 \%)$; 7,787.34 ha of pastures $(51.09 \%)$; 7.82 ha of exposed soil $(0.05 \%)$, and 11.88 ha of floodplain areas $(0.08 \%)$.

The analysis of land use in the field study also shows that the pasture are the plant coverings that occupy most of the area, representing more than 50\% (51.09\%), i.e., covering 7,787.34 ha. In an earlier study, CAMPOS et al. (2010) showed that in pasture places there is a predominance of soils of low fertility.

After classification of the image obtained by scanning in manual screen (ground truth), with visual interpretation of the features identified in satellite imagery, confirmed in Google Earth and by field visits, the Kappa index calculated on the results of this classification approach was 0.78, so the classification is taken by LANDIS and KOCH (1977) as being very good.

TABLE 1. Soil use classes in the Água Fria Stream watershed - Bofete, SP - Brazil.

\begin{tabular}{crc}
\hline Use Classes & Area (ha) & \% In Relation to Watershed \\
\hline Forest & $4,932.9$ & 32.36 \\
Reforestation & $2,502.9$ & 16.42 \\
Pasture & $7,787.34$ & 51.09 \\
Exposed Soil & 7.82 & 0.05 \\
Floodplain & 11.88 & 0.08 \\
\hline Total & $15,242.84$ & 100 \\
\hline
\end{tabular}

Reforestation occupies nearly $1 / 6$ of the watershed and should be increasingly improved for the region as a means of rational and integrated protection of the area, mainly because these activities show great economic returns to the region (CAMPOS et al., 2010).

The forests (riparian forests, cerrados and forests themselves) and pastures occupy almost $83.45 \%$ of the area covered by the watershed, reflects of the predominance of low fertility soils.

The natural forests represent $32.36 \%$ of occupation of the area. This result is in agreement with the Brazilian Forest Code (1965), which stipulates a minimum reserve of $20 \%$. 
The survey of land use, in a given region, becomes an aspect of fundamental interest for understanding the patterns of spatial organization. By knowing the changes caused by human action, it can get a view of the existing problems and make allowances for natural resource management. It is prerequisite to program a policy of rational land use and respect to susceptibility and the support capacity of the environment to human impacts, enabling the socio-economic development.

The areas of permanent preservation are fundamental within a watershed, as they are characterized primarily by riparian forests that are responsible for a whole process of conservation and maintenance of a particular river system. These refer to both springs and along a certain watercourse.

The watershed has a total area of PPAs of 993.26 ha, of which 58.21 ha (5.85\%) are composed of headwater areas and 935.1 ha $(94.15 \%)$ of permanent preservation areas along watercourses.

The uses for occupations soil of pasture, reforestation and soil exposed inappropriately in permanent preservation areas may be considered conflicts, while the occupations of forests and floodplains in PPAs are considered a natural part.

It can be checked that the conflictive areas in PPAs (Figure 4 and Table 2) represent 343.07 ha, of which 302.41 ha $(88.15 \%)$ correspond to pasture, 35.76 ha (10.42\%) to the reforested areas, and 4.9 hectares $(1.43 \%)$ are occupied by exposed soil.

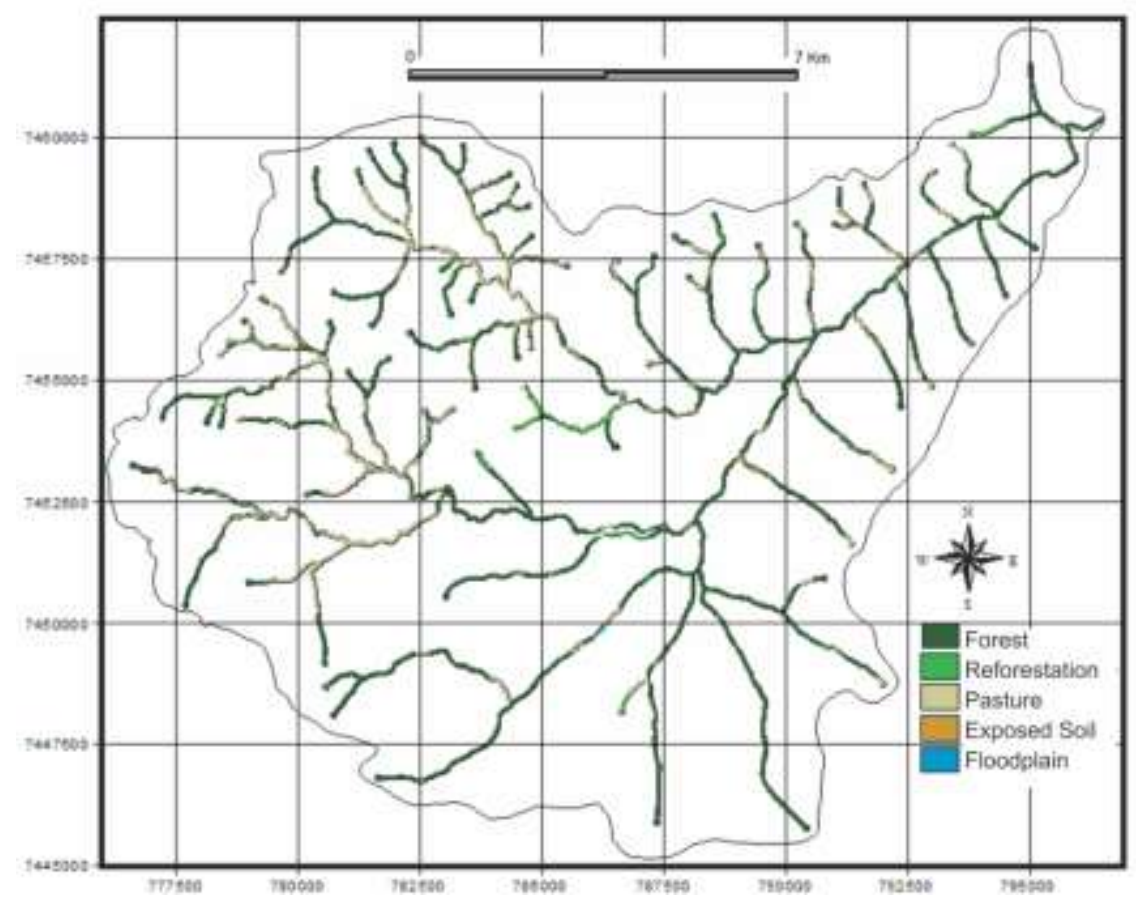

FIGURE 4. Soil use conflicts in PPAs in the Água Fria Stream watershed - Bofete, SP - Brazil.

TABLE 2. Soil use conflicts in PPAs in the Água Fria Stream watershed - Bofete, SP - Brazil.

\begin{tabular}{crrcc}
\hline \multirow{2}{*}{ Use Classes } & \multicolumn{2}{c}{ Permanent Preservation Areas } & \multicolumn{2}{c}{ Conflicts in PPAs } \\
\cline { 2 - 5 } & \multicolumn{1}{c}{ ha } & $\%$ & - & ha \\
\hline Forest & 648.38 & 65.3 & 35.76 & 10.4 \\
Reforestation & 35.76 & 3.6 & 302.41 & 88.1 \\
Pasture & 302.41 & 30.4 & 4.90 & 1.4 \\
Exposed Soil & 4.90 & 0.5 & - & - \\
Floodplain & 1.81 & 0.2 & 343.07 & 100 \\
\hline Total & 993.26 & 100 &
\end{tabular}


When analyzing the results contained in Table 2, we note that most of the conflicting areas are occupied by pastures $(88.15 \%)$ and the remainder by reforestation $(10.42 \%)$ and exposed soil (1.43\%), demonstrating that the watershed has a good plant cover, but about a third of permanent preservation areas has been suffering with human actions over the years, mainly by pasture. This, according to NARDINI (2009), brings environmental damage such as erosion and leaching of materials inside the watercourses by the lack of riparian vegetation, resulting in siltation of part of the hydrography network of the watershed.

\section{CONCLUSIONS}

The results demonstrated that the watershed is occupied by $2 / 3$ of pasture and reforestation, reflecting the predominance of sandy soils and low fertility. The permanent preservation areas were occupied by pastures, corresponding to $1 / 3$. The geographic information systems were essential tools in achieving the maps of land use and occupation, of the permanent preservation areas, and of conflicts, especially for future planning in the region.

\section{REFERENCES}

BRASIL. Lei Federal no 4.771, de 15 de setembro de 1965. Institui o Novo Código Florestal Brasileiro. Diário Oficial da República Federativa do Brasil, Poder Executivo, Brasília, DF, 20 set. 1965, p.9513.

CAMPOS, S.; GRANATO, M.; BARBOSA, A.P.; SOARES, M.C.E.; PISSARRA, T.C.T. Geoprocessamento aplicado na identificação e localização potencial de conflitos de uso em APPs. In: CONGRESO LATINOAMERICANO Y DEL CARIBE DE INGENIERÍA AGRÍCOLA, 9., 2010, Vitória. Anais... Jaboticabal: SBEA, 2010. 1 CD-ROM.

CAMPOS, S.; PISSARRA, T.C.T.; RODRIGUES, F.M.; SILVA, M.G.; SOARES, M.C.E.; GRANATO, M.; CAVASINI, R.; MOREIRA, K.F. Imagens digitais na análise do uso da terra de uma microbacia como subsídio ao desenvolvimento sustentável. Agrarian, Dourados, v.3, n.9, p.209-215, 2010.

LANDIS, J.R.; KOCH, G.G. The measurement of observer agreement for categorical data. Biometrics, Michigan, v.33, n.1, p.159-174, 1977.

NARDINI, R.C. Determinação do conflito de uso e ocupação do solo em áreas de preservação permanente da microbacia do Ribeirão Água Fria - Bofete (SP), visando à conservação dos recursos hídricos. 2009. 61 f. Dissertação (Mestrado em Irrigação e Drenagem) - Faculdade de Ciências Agronômicas, Universidade Estadual Paulista, Jaboticabal, 2009. 